f. Reprod. Fertil. (1961) 2, 80-97

\title{
FACTORS AFFECTING THE FERTILITY OF MICE WITH ORTHOTOPIC OVARIAN GRAFTS
}

\author{
MARJORIE V. MUSSETT AND DELPHINE M. V. PARROTT* \\ Divisions of Biological Standards and Experimental Biology, \\ National Institute for Medical Research, London, N.W.7
}

(Received 16th August 1960)

Summary. Female mice of four different strains were sterilized by $\mathrm{X}$-irradiation and received orthotopic grafts of ovarian tissue from donors of the same strain.

A linear relationship was demonstrated between log. age and the number of oocytes in both normal ovaries and orthotopically grafted ovarian tissue of $\mathrm{G}$ strain $\left(\mathrm{CBA} / \mathrm{Fa}-\mathrm{a}^{\mathrm{t}}\right)$ mice. It was calculated from the regressions that an average of $65 \%$ of the oocytes in the implanted tissue was lost within a few days of grafting. However, the subsequent rate of oocyte loss was reduced so that the potential reproductive life of the recipient mice was not drastically shortened.

The average size of litters born to graft recipients was less than that recorded in normal mice with the same number of oocytes. It was considered that obstruction or splitting of the ovarian capsules of the grafted animals resulted in the loss of many ova. Shortage of oocytes or mature follicles did not appear to be a major factor in determining litter size.

Other variables, including the interval between sterilization of recipients by $\mathrm{X}$-irradiation and grafting, the age of donors and the volume of graft material, were also investigated in relation to the fertility of the grafted mice. Increased foetal resorption in two strains was noted.

\section{INTRODUCTION}

In 1956, Parrott \& Parkes described a technique for the orthotopic grafting of ovarian tissue in mice sterilized by X-irradiation. Approximately $80 \%$ of all mice with established grafts were fertile (Parrott \& Parkes, 1960) but although many of the recipients had several litters the average number of offspring in each litter was small. Complete infertility was usually due to blockage of the periovarian space (Parrott, 1958) and it was suggested that the small litters were the result of partial obstructions which would prevent many ova reaching the Fallopian tube and being fertilized. More recently, it has been demon-

* Present address: Imperial Cancer Research Fund, London, N.W.7. 
strated both in mice (Jones \& Krohn, 1960) and in rats (Parrott, 1960) that there were considerable losses of oocytes from ovarian tissue implanted orthotopically; this might also result in a reduction of litter size. The work of S. Zuckerman and his associates has shown that there is no new formation of oocytes in ovarian tissue after birth (for references, see Zuckerman, 1951, 1956) and while this does not place a limitation on reproduction in the normal animal, since oocytes are present in excess of requirements, it could restrict the fertility of the grafted animal with its already depleted stock of oocytes.

The experiments on mice, described in this paper, were designed to estimate the percentage of oocytes lost on orthotopic grafting and to compare the subsequent rate of oocyte loss with that in normal animals. Fertility of recipients was assessed by comparing the number and size of litters obtained from normal and grafted mice.

The effects of other factors including the age of the donors and of the implanted tissue, the interval between irradiation and grafting and foetal resorption during pregnancy were also investigated.

Most of the experiments were carried out with mice of the G strain. This is an inbred strain in which three different types of coat colour are found and, by the use of donors and recipients of different phenotypes, offspring derived from a graft may be readily distinguished from the recipient's own offspring. Mice from three other strains were also used, but although there was ample evidence that the offspring born to recipients were derived from the grafts they were not genetically identified.

\section{ANIMALS AND TECHNIQUES}

$C B A / F a-a^{t}$ or $G$ strain. Two females and one male of the inbred strain $\mathrm{CBA} / \mathrm{Fa}-\mathrm{a}^{\mathrm{t}}$ or $\mathrm{G}$ line mice were obtained from Dr D. S. Falconer in Edinburgh and a colony established at the National Institute for Medical Research in 1957. This strain carries the gene $a^{t}$ or 'black and tan' which was introduced by back crosses into the CBA strain. There are three genotypes within the strain:
AA: agouti with agouti belly
Aat: agouti with tan belly
$\mathrm{a}^{\mathrm{t}} \mathrm{a}^{\mathrm{t}}$ : black with $\tan$ belly

The strain is maintained by brother-sister matings of the genotypes $\mathrm{Aa}^{\mathrm{t}} \times \mathrm{Aa}^{\mathrm{t}}$ and this gives the above genotypes in the ratio $1: 2: 1$. It is therefore assumed that the strain remains genetically homogeneous and still differs from the CBA strain by only a single gene substitution although skin-graft tests have not been carried out. The two homozygotes, AA and $a^{t} a^{t}$, were used in the grafting experiments.

$C B A, T O$ and $R$ strains. These were the three other strains of mice used in the experiments. A full description of these strains, grafting techniques and the method of counting oocytes has been published elsewhere (Parrott, 1960). 


\section{RESULTS}

NUMBERS OF OOGYTES AND AGE IN NORMAL G STRAIN MICE

Counts were made of the oocytes in both ovaries of twenty-eight normal $\mathrm{G}$ strain mice from the breeding colony aged from 21 to 469 days. The oocyte counts decreased progressively with increasing age, and exhaustion occurred at approximately 400 days (Text-fig. 1). Jones \& Krohn (1959) found a linear

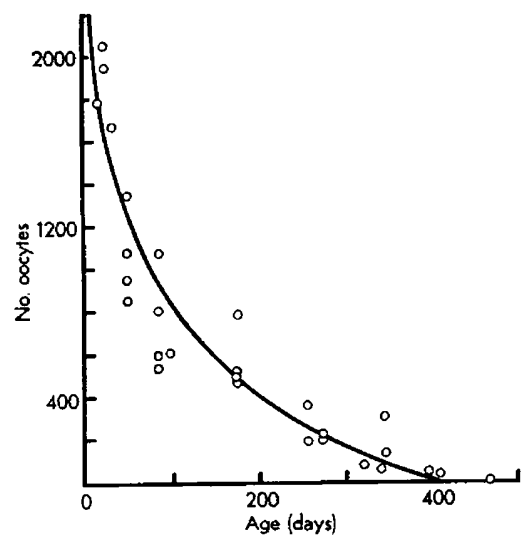

TExT-FIG. 1. Oocyte loss in normal G strain mice.

relationship between log. oocytes and age in mice of the CBA strain. When the results obtained with $G$ strain (a substrain of CBA mice) were expressed in this way, the relationship was found to be curvilinear, but a straight line could be

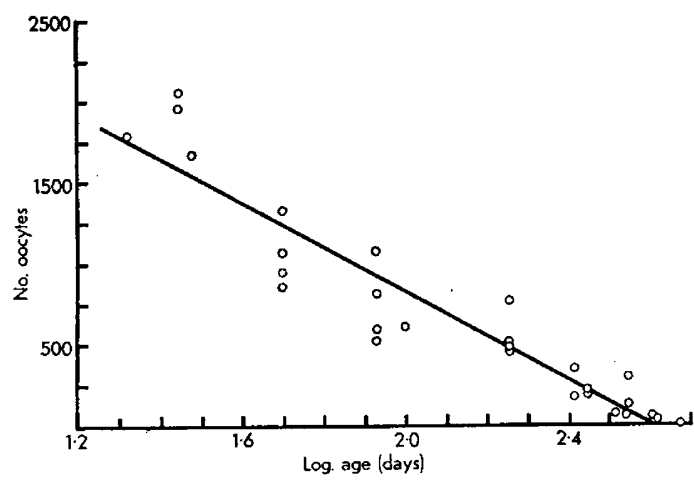

TExT-FIG. 2. Oocyte loss in normal G strain mice (number of oocytes $=3564-1367$ log. age).

fitted when number of oocytes was related to log. age, the regression of oocytes on log. age being: $y=3564-1367 \log$. $x$, where $x=$ age in days and $y=$ the number of oocytes (Text-fig. 2). The curve of oocyte number against actual age (Text-fig. 1) was derived from this equation. 


\section{LOSS OF OOCYTES IN GRAFTED ANIMALS}

Forty-one $G$ strain mice, all having had at least one pregnancy following orthotopic grafting, were killed at various time intervals of from 33 to 137 days after operation and the number of oocytes remaining in the grafted tissue was counted. In the analysis of these results, there were four variables to be taken into account, i.e. the age of the donor, the age of the recipient, the time between grafting and death of the recipient, and the amount of ovarian tissue implanted into each ovarian capsule. The age of the recipients was relatively constant and was ignored in the calculations, but in order to isolate the other variables the results were divided into five groups according to the age of the donor and the amount of implanted tissue, as in Table 1.

TABLE 1

DESIGN OF EXPERIMENT

\begin{tabular}{c|c|c|c}
\hline Group & $\begin{array}{c}\text { Amount of } \\
\text { tissue grafted } \\
\text { into each } \\
\text { capsule }\end{array}$ & $\begin{array}{c}\text { Age of donor } \\
\text { (days) }\end{array}$ & $\begin{array}{c}\text { No. } \\
\text { recipients* }\end{array}$ \\
\hline 1 & Whole ovary & 19 to 27 & 11 \\
2 & Whole ovary & 31 to 38 & 5 \\
3 & Whole ovary & 43 to 51 & 7 \\
4 & Half ovary & 28 to 38 & 11 \\
5 & Half ovary & 56 & 7 \\
\hline
\end{tabular}

* Aged 2 to 3 months at grafting operations.

The regression of oocyte number on the logarithm of the number of days between grafting and death was calculated for each of the five groups and led

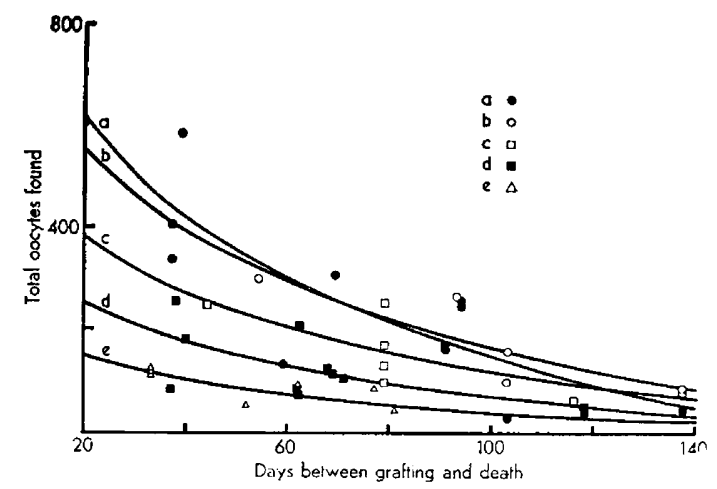

TEXT-FIG. 3. Oocyte loss in grafts from $G$ strain mice.

$$
\left.\begin{array}{l}
\text { a: Age of donor } 19 \text { to } 27 \text { days } \\
\text { b: Age of donor } 31 \text { to } 38 \text { days } \\
\text { c: Age of donor } 43 \text { to } 51 \text { days } \\
\text { d: Age of donor } 28 \text { to } 38 \text { days } \\
\text { e: Age of donor } 56 \text { days }
\end{array}\right\} \begin{gathered}
\text { whole-ovary } \\
\text { grafts } \\
\text { half-ovary } \\
\text { grafts }
\end{gathered}
$$

to a series of oocyte-time curves (Text-fig. 3). It now became clear that the expected number of oocytes at any time after grafting was related to the age of the donor mouse, and when the curves were plotted as oocyte number 
against the actual age of ovarian tissue (i.e., the age of the donor plus the time between grafting and death) they were almost coincident (Table 2).

TABLE 2

EXPECTED NUMBER OF OOCYTES IN GRAFTED TISSUE

\begin{tabular}{c|c|c|c|c|c}
\hline $\begin{array}{c}\text { Actual age } \\
\text { of ovarian } \\
\text { graft (days) }\end{array}$ & \multicolumn{5}{|c|}{ Group* according to age of donor and size of implant } \\
\hline 60 & 1 & 2 & 3 & $4 \dagger$ & $5 \dagger$ \\
\hline 80 & 434 & 501 & 457 & 435 & 497 \\
100 & 309 & 360 & 303 & 310 & 272 \\
120 & 222 & 271 & 226 & 230 & 196 \\
140 & 156 & 207 & 173 & 172 & 149 \\
160 & 101 & 155 & 133 & 125 & 115 \\
180 & 56 & 113 & 101 & 87 & 88 \\
200 & 16 & 77 & 74 & 54 & 66 \\
& - & 46 & 51 & 25 & 48 \\
\hline
\end{tabular}

* See Table 1

$\uparrow$ Numbers of oocytes multiplied by two in each of these groups.

The donor age was, therefore, eliminated by regrouping into whole-ovary and half-ovary grafts and calculating the regressions of oocyte number on log. ovarian age for each group, now containing twenty-three and eighteen observations, respectively.

The regression equations were:

$$
\begin{aligned}
& y=1782-769 \log . x^{\prime} \text { (whole ovary) } \\
& y=819-355 \log . x^{\prime} \text { (half ovary) }
\end{aligned}
$$

where $\mathrm{x}^{\prime}$ represents the age of the donor mouse plus the time between grafting and death of the recipient.

The expected number of oocytes estimated from these equations have been

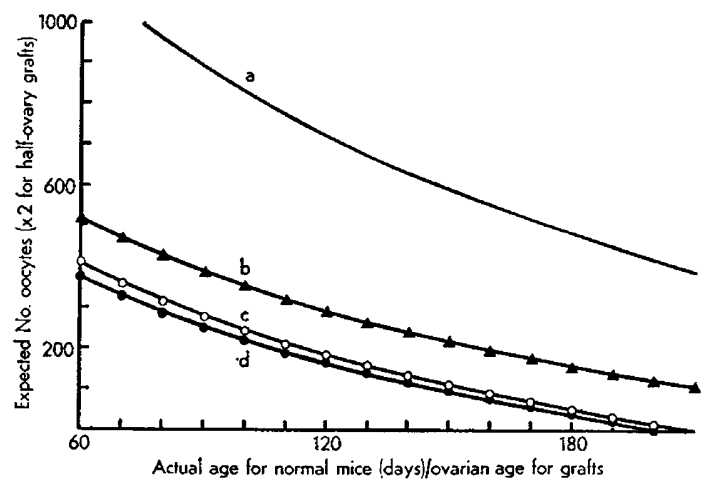

TEXT-FIG. 4. Comparison between numbers of oocytes in normal and grafted $G$ strain mice.

a: Normal $G$ strain (28 animals).

b: Grafted and irradiated same day (6 animals).

c: Whole-ovary grafts (23 animals).

d: Half-ovary grafts (18 animals).

plotted in Text-fig. 4, together with a section of the curve from normal G mice for comparison. (The results from an additional group of grafted mice in 
which the experimental procedure was varied are also included in Text-fig. 4; these will be discussed later.) The values obtained directly from the second equation were multiplied by two before plotting, to make them equivalent to the estimates for the whole-ovary grafts.

\section{INITIAL LOSS OF OOCYTES ON GRAFTING}

It will be seen from Text-fig. 4 that the numbers of oocytes found in the grafted ovaries were considerably less than those obtained for normal mice of the same ovarian age. It is estimated that about $65 \%$ of oocytes were lost at the

TABLE 3

NUMBERS OF OOGYTES IN GRAFTS FROM FERTILE MICE AND NORMAL MICE OF GBA, R AND TO STRAINS

\begin{tabular}{|c|c|c|c|c|c|c|}
\hline \multicolumn{7}{|c|}{$C B A$ mice } \\
\hline & $\begin{array}{l}\text { Age in } \\
\text { days or } \\
\text { days after } \\
\text { grafting }\end{array}$ & \multicolumn{3}{|c|}{$\begin{array}{l}\text { Whole-ovary grafts. } \\
\text { Donors } 8 \text { to } 9 \text { days }\end{array}$} & \multicolumn{2}{|c|}{$\begin{array}{l}\text { Whole-ovary grafts. } \\
\text { Donors } 56 \text { to } 60 \text { days }\end{array}$} \\
\hline & $\begin{array}{r}33 \\
67 \\
71 \\
83 \\
109\end{array}$ & $\begin{array}{l}379 \\
724 \\
193,3\end{array}$ & 79 , & 561, & \multicolumn{2}{|c|}{$72,125,213,234,288$} \\
\hline \multicolumn{7}{|c|}{$R$ hybrid mice } \\
\hline $\begin{array}{l}\text { Age in } \\
\text { days or } \\
\text { days after } \\
\text { grafting }\end{array}$ & \multicolumn{3}{|c|}{ Normal mice } & \multicolumn{2}{|c|}{$\begin{array}{l}\text { Whole-ovary grafts. } \\
\text { Donors } 25 \text { to } 35 \text { days }\end{array}$} & $\begin{array}{l}\text { Half-ovary grafts. } \\
\text { Donors } 25 \text { to } 35 \text { days }\end{array}$ \\
\hline $\begin{array}{r}82 \\
117 \\
125 \\
133 \\
459 \\
524\end{array}$ & \multicolumn{3}{|c|}{$\begin{array}{l}394,840,965,1138,1303 \\
218,527,702,818,1040\end{array}$} & \multicolumn{2}{|c|}{$405,599,935,1632$} & $\begin{array}{l}210,246,252,376 \\
100,208,262,503,736\end{array}$ \\
\hline \multicolumn{7}{|c|}{ TO mice } \\
\hline & & $\begin{array}{l}\text { Age in } \\
\text { days or } \\
\text { days after } \\
\text { grafting }\end{array}$ & & & $\begin{array}{l}\text { Whole-ovary } \\
\text { grafts. } \\
\text { Donors } \\
10 \text { to } 16 \text { days }\end{array}$ & \\
\hline & & $\begin{array}{r}31 \\
32 \\
37 \\
39 \\
45 \\
62 \\
63 \\
67 \\
113 \\
146\end{array}$ & $\begin{array}{l}25 \\
49\end{array}$ & 404 & $\begin{array}{l}179,476,1018 \\
165,1400 \\
0 \\
548 \\
933,1123,1823 \\
81,748 \\
307,491,877\end{array}$ & \\
\hline
\end{tabular}


time of grafting, this figure being derived from a comparison of the regressions for normal and grafted mice at an ovarian age of 60 days. This time is equivalent to 4 to 41 days after grafting for individual mice.

It is probable that several different factors contributed to this initial loss. Some tissue may have been destroyed during dissection; known amounts of tissue were placed in each ovarian capsule but since this was not sutured some displacement may have occurred. Ischaemia resulting from the inevitable delay in vascularization would certainly cause the destruction of some oocytes. No attempt was made to assess the relative importance of these factors.

Experiments were also carried out with three other strains of mice, CBA, R and TO. Regressions of oocyte loss against age were not calculated but it is probable that the initial destruction of oocytes was comparable to that which occurred in the G mice (Table 3). Results from the R hybrid and TO outbred stocks were complicated by the variable destruction of tissue by homograft reaction. An average of 6.4 out of $10 \mathrm{TO}$ mice rejected the implanted tissue within 14 days. The survival time of the accepted grafts was dependent upon not only the number of oocytes that survived the trauma of grafting but also the degree of compatibility between the donor and host and was, in consequence, very variable.

RATE OF OOCYTE LOSS IN NORMAL AND GRAFTED G STRAIN MICE

The percentage loss of oocytes per 10 days was estimated, for both normal and grafted mice, by use of the formula:

$$
\text { Percentage loss per } 10 \text { days }=100 \frac{\log \cdot \frac{\mathrm{D}+10}{\mathrm{D}}}{\mathrm{A}-\log \cdot \mathrm{D}^{\prime}}
$$

where $\mathrm{D}$ is the day at the beginning of the 10-day period under consideration, and $\mathrm{A}$ is the ratio of the two constants (intercept divided by slope) in the appropriate regression equation. The calculated values, therefore, represent the estimated number of oocytes lost in a 10-day interval, expressed as a percentage of the number of oocytes estimated to be present at the beginning of the interval. This loss was high in normal mice during the first few weeks but it remained comparatively stable at $6 \frac{1}{2}$ to $8 \%$ from 60 to 250 days and then increased dramatically towards the end of life (Text-fig. 5). The percentage loss of oocytes per 10 days was greater in both the whole and half grafts than in the ovaries from normal animals of the same age. However, these differences and the increased percentage loss in both normal and grafted mice towards the end of life were consequences of the percentages being based on smaller numbers of oocytes. The actual number lost per 10 days decreased with increasing age and was less in the grafted than in the normal ovaries (Text-fig. 6). In fact, when the percentage losses were related to the actual number of oocytes present rather than ovarian age, the results from the whole-ovary-graft recipients were directly comparable to those from normal mice (Table 4). 
The percentage losses of oocytes from the half-ovary grafts were appreciably less than those from either the whole grafts or normal ovaries (Table 4),

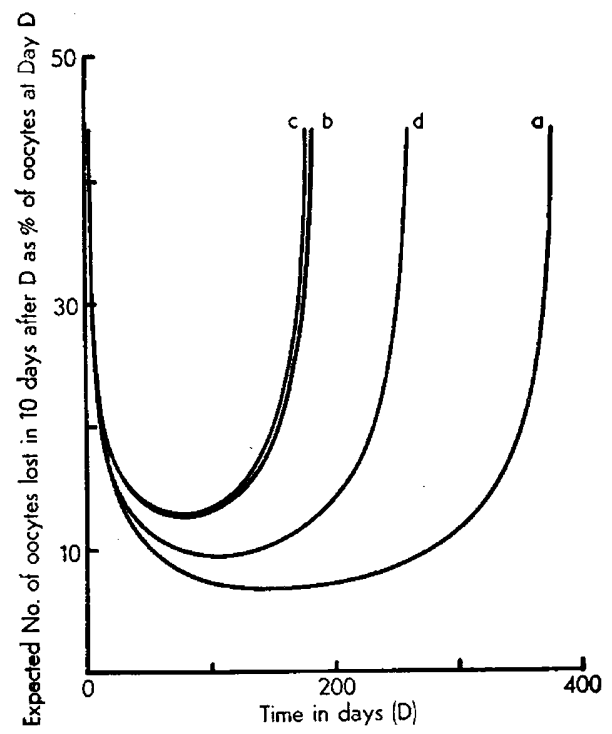

Text-Fig. 5. Percentage oocyte loss per 10 days.

a: Normal G strain.

b: Whole-ovary graft.

c: Half-ovary graft.

d: Grafted and irradiated same day.

TABLE 4

PERCENTAGE LOSS PER 10 DAYS RELATED TO NUMBERS OF OOCYTES IN OVARIAN TISSUE FROM G STRAIN MICE

\begin{tabular}{c|c|c|c|c}
\hline & \multicolumn{4}{|c}{ Percentage loss per 10 days } \\
\cline { 2 - 4 } $\begin{array}{c}\text { No. } \\
\text { oocytes }\end{array}$ & $\begin{array}{c}\text { Normal } \\
\text { ovaries }\end{array}$ & $\begin{array}{c}\text { Whole-ovary } \\
\text { grafts }\end{array}$ & $\begin{array}{c}\text { Half-ovary } \\
\text { grafts }\end{array}$ & $\begin{array}{c}\text { Half-ovary } \\
\text { grafts } \\
\text { (no interval } \\
\text { between } \\
\text { irradiation } \\
\text { and grafting) }\end{array}$ \\
& & & & 40 \\
15 & & & & 26 \\
25 & & & 54 & 23 \\
30 & 55 & 58 & 34 & 15 \\
50 & 31 & 37 & 20 & 10 \\
100 & 17 & 21 & 14 & 9 \\
150 & 12 & 16 & 13 & 10 \\
200 & 10 & 14 & 13 & 11 \\
250 & 9 & 13 & 14 & \\
300 & 8 & 12 & 15 & \\
400 & 7 & 12 & & \\
500 & 7 & 13 & & \\
600 & 7 & 14 & & \\
\hline
\end{tabular}

although the same number of oocytes was present. This suggests that oocyte loss is normally dependent upon the number present but when this is small other factors such as the distribution of oocytes, may become more important. 
The number of large and medium follicles was also found to be directly related to the total number of oocytes, when there were less than 400 in the G strain and 600 in the $R$ hybrid mice (Text-figs. 7 and 8). Above these values, the number of large and medium follicles remained relatively constant. There was, however, no evidence to suggest that the maturation of follicles was abnormal in the grafted ovarian tissue.

EFFECT OF REDUCED NUMBER OF OOGYTES IN GRAFTED TISSUE ON FERTILITY OF RECIPIENTS

The fertility of the $G$ strain breeding colony was poor. The average size of litters was below that of most strains and concurrent lactation and pregnancy occurred infrequently. There was a gradual decline in both the average number of offspring in each litter (Table 5) and in the proportion of paired mice having litters which corresponded with the decline in numbers of oocytes. In fact, cessation of reproduction, oocyte exhaustion and death followed in fairly close succession in this strain of mice.

The most important effect of the large initial loss of oocytes from the implanted tissue and the subsequent increased rate of loss of oocytes was that total depletion would have occurred by 180 to 200 days after grafting. At this time, the average age of the recipients would have been 240 days. Since oocyte exhaustion does not occur in normal G strain mice until about 400 days of age, the potential reproductive life of the graft recipients was curtailed. The number of oocytes remaining in grafts from R, CBA and some TO mice was much greater than in G strain grafts of comparable age (Table 3). However, it is probable that much greater numbers of oocytes were present in the donor tissues at the time of grafting and that a similar initial loss of oocytes with a consequent curtailing of reproductive life also occurred in these strains. There was considerable variability in some of the results from the TO, an outbred stock, and the R, a mixed hybrid of inbred and outbred strains. This was probably due to two factors, the heterogeneous origin of both stocks and a variable destruction of oocytes by homograft reaction.

The post-operative history of the five groups of $\mathrm{G}$ strain recipients is detailed in Table 6. Altogether forty-two litters were born, twenty-five litters were raised and all the offspring were of the Aat genotype. No litters of mixed origin were recorded.

The average size of litters in all five groups was small. However, despite considerable differences in the numbers of available oocytes between the wholeand half-ovary groups (Text-fig. 3), there was no significant difference in the average size of the litters born to each group. Nor was there a progressive decrease in the average size of successive litters in each group, in spite of the continuing decline in the numbers of oocytes. Moreover, normal mice having the same number of oocytes available as the whole-ovary-graft recipients had litters with a greater average number of offspring. The results from the $\mathrm{R}$ hybrid mice (Table 7) were similar in several respects to those obtained with the G strain recipients. The average size of litters born to recipients with wholeovary grafts was less than that in both normal mice of the same age as the 


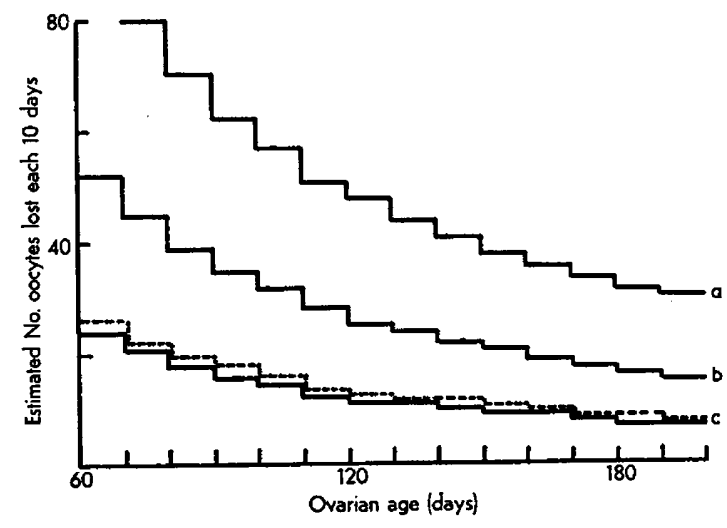

Texr-Fig. 6. Oocyte loss related to ovarian age.

a: Normal strain.

b: Whole-ovary graft.

c-: Half-ovary graft.

c- - : Half-ovary graft and irradiated same day.

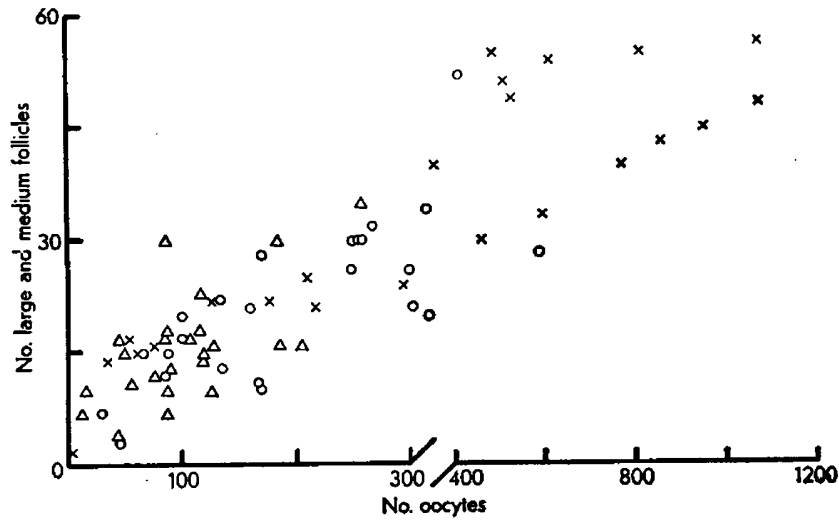

TEXT-FIG. 7. The number of large and medium follicles to total numbers of oocytes in $G$ strain mice (minimum age 50 days).

$X$ : Normal mice. $O$ : Whole-ovary-graft recipients. $\triangle:$ Half-ovarygraft recipients.

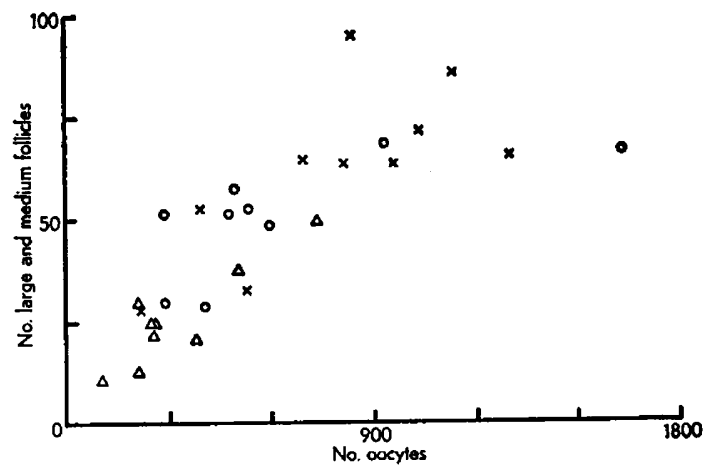

TExT-FIG. 8. The number of large and medium follicles to total numbers of oocytes in $R$ hybrid mice (minimum age 100 days). $X$ : Normal mice. $O$ : Whole-ovary-graft recipients. $\triangle$ : Half-ovary-graft recipients. 


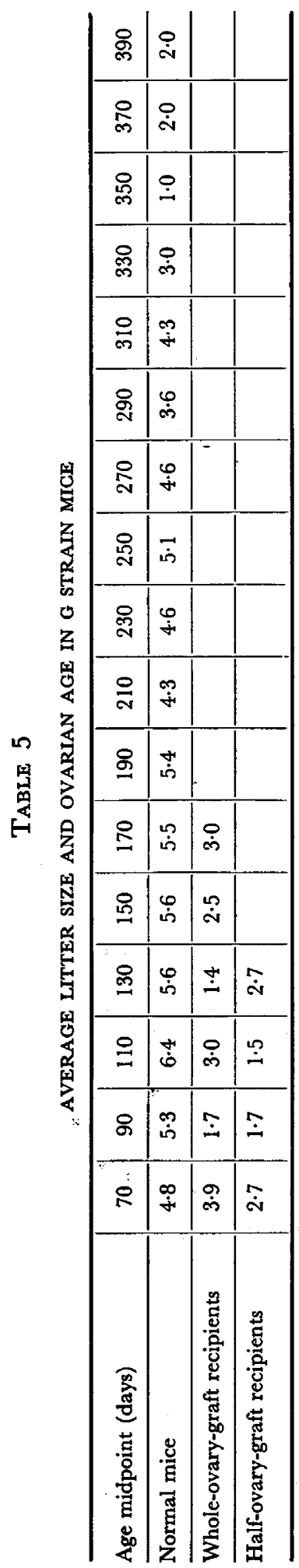


grafted tissue and in much older mice with approximately the same number of oocytes. There was again only a slight reduction in the average size of litters born to half-ovary graft recipients, although the number of oocytes available was on average only half of that present in the whole-ovary grafts. Thus the

TABLE 6

FERTILITY OF G STRAIN GRAFT RECIPIENTS

\begin{tabular}{|c|c|c|c|c|c|c|c|}
\hline \multirow{2}{*}{ Group } & \multirow{2}{*}{$\begin{array}{l}\text { No. mice } \\
\text { paired }\end{array}$} & \multirow{2}{*}{$\begin{array}{l}\text { No. pseudo- } \\
\text { pregnancies }\end{array}$} & \multirow{2}{*}{$\underset{\text { pregnancies }}{\text { No. }}$} & \multirow{2}{*}{$\begin{array}{l}\text { No. killed } \\
\text { pregnant }\end{array}$} & \multirow{2}{*}{$\begin{array}{l}\text { No. } \\
\text { litters }\end{array}$} & \multicolumn{2}{|c|}{ Litter size } \\
\hline & & & & & & Average & Range \\
\hline $\begin{array}{l}\text { Whole-ovary grafts } \\
19-\text { to } 27 \text {-day donors }\end{array}$ & 11 & 12 & 25 & 5 & 9 & $2 \cdot 8$ & 1 to 6 \\
\hline $\begin{array}{l}\text { Whole-ovary grafts } \\
31 \text { - to 38-day donors } \\
\text { Whole-ovary grafts }\end{array}$ & 5 & 3 & 16 & 2 & 11 & $2 \cdot 5$ & 1 to 6 \\
\hline $\begin{array}{l}\text { 43- to } 51 \text {-day donors } \\
\text { Half-ovary grafts }\end{array}$ & 7 & 8 & 14 & 2 & 10 & $2 \cdot 1$ & 1 to 4 \\
\hline $\begin{array}{l}\text { 28- to } 38 \text {-day donors } \\
\text { Half-ovary grafts }\end{array}$ & 11 & 2 & 21 & 4 & 10 & $2 \cdot 1$ & 1 to 4 \\
\hline $\begin{array}{l}\text { 56-day donors } \\
\text { Grafting and }\end{array}$ & 7 & 2 & 9 & 2 & 2 & $3 \cdot 0$ & 2 to 4 \\
\hline $\begin{array}{l}\text { irradiating same day } \\
38 \text { - to 62-day donors }\end{array}$ & 7 & 0 & 20 & 1 & 10 & $3 \cdot 3$ & 2 to 5 \\
\hline
\end{tabular}

results from both the $\mathrm{G}$ strain and the $\mathrm{R}$ hybrid stock showed that the loss of oocytes that followed grafting was not the sole cause of small litters in graft recipients. Differences in fertility between the five groups of $G$ strain mice were characterized by the proportion of matings that resulted in the birth of live

TABLE 7

FERTILITY OF CBA, R AND TO MICE

\begin{tabular}{|c|c|c|c|c|c|c|}
\hline \multirow{2}{*}{ Group } & \multirow{2}{*}{$\begin{array}{l}\text { No. mice } \\
\text { paired }\end{array}$} & \multirow{2}{*}{$\begin{array}{l}\text { No. pseudo- } \\
\text { pregnancies }\end{array}$} & \multirow{2}{*}{$\underset{\text { pregnancies }}{\text { No. }}$} & \multirow{2}{*}{$\begin{array}{l}\text { No. } \\
\text { litters }\end{array}$} & \multicolumn{2}{|c|}{ Litter size } \\
\hline & & & & & Average & Range \\
\hline $\begin{array}{l}\text { CBA whole-ovary grafts } \\
\text { 8- to 9-day donors }\end{array}$ & 8 & 8 & 12 & 7 & $2 \cdot 4$ & 1 to 4 \\
\hline CBA whole-ovary grafts & & & & & & \\
\hline $\begin{array}{l}56-\text { to } 60 \text {-day donors } \\
\mathbf{R} \text { whole-ovary grafts }\end{array}$ & 6 & 3 & 15 & 7 & $3 \cdot 1$ & 2 to 5 \\
\hline $\begin{array}{l}25 \text { - to } 35 \text {-day donors } \\
\mathrm{R} \text { half-ovary grafts }\end{array}$ & 12 & 3 & 31 & 28 & $3 \cdot 0$ & 1 to 12 \\
\hline $\begin{array}{l}25-\text { to } 35 \text {-day donors } \\
\mathbf{R} \text { normal mice }\end{array}$ & $\begin{array}{l}11 \\
10\end{array}$ & $\begin{array}{l}3 \\
3\end{array}$ & $\begin{array}{l}32 \\
30\end{array}$ & 28 & $2 \cdot 5$ & 1 to 6 \\
\hline $\begin{array}{l}\text { R normal mice } \\
\text { TO whole-ovary grafts }\end{array}$ & 10 & 3 & 30 & 19 & 0.3 & 2 to 12 \\
\hline 10- to 16 -day donors & 15 & 4 & 29 & 23 & $3 \cdot 1$ & 1 to 7 \\
\hline
\end{tabular}

litters rather than in average litter size. Complete foetal resorption during pregnancy was frequent in all groups, especially after the first fertile matings, and this problem will be discussed in greater detail later. The most successful mice were the whole-ovary recipients with tissue from 31- to 38-day-old donors, those with tissue from 43- to 51-day-old donors and the half-ovary-graft recipients with ovaries from 28- to 38-day-old donors; the number of litters 
born to mice of these groups expressed as a percentage of pregnancies and pseudopregnancies was $64 \cdot 7,50 \cdot 0$ and $52 \cdot 6$, respectively. In the whole-ovary recipients with ovaries from 19- to 27-day-old donors, both resorptions and pseudopregnancies were very frequent and only $28 \%$ of matings resulted in the birth of litters. The half-ovary-graft recipients with tissue from 56-day-old donors were the least successful; matings were infrequent and most of these were unsuccessful; there were seven fertile matings (excluding two animals killed in pregnancy) but there were only two litters. In the three most successful groups, the proportion of paired mice giving birth to litters was approximately the same as in normal $\mathrm{G}$ mice. CBA mice with orthotopic grafts gave very similar results to the $G$ strain (Table 7 ), $37 \%$ of all matings resulting in live litters, but in the $\mathrm{R}$ hybrid a much higher proportion of matings was successful. Eighty-two per cent of the matings in mice with whole-ovary grafts (Table 7) and $65 \%$ in mice with half-ovary grafts (Parrott \& Parkes, 1956) resulted in the birth of litters.

\section{RESORPTION OF FOETUSES DURING PREGNANGY}

Parrott \& Parkes (1960) reported that complete failure of pregnancy was a frequent occurrence in CBA strain mice with orthotopic grafts. Mating was followed in due course by a normal 'implantation sign' but no live birth. Between 13 and 17 days after coitus, there was a bloody discharge from the vagina accompanied by a rapid loss of weight; subcutaneous injections of progesterone or progesterone plus oestrogen did not reduce the frequency of resorption. This phenomenon occurred very often in $\mathrm{G}$ mice with orthotopic grafts and also occasionally in $\mathrm{R}$ hybrid and TO graft recipients and in old normal $G$ and $R$ mice. It was very infrequent in normal animals of the same age as the grafted tissue.

Since loss of all the foetuses in utero was a frequent occurrence in graft recipients, it was considered possible that resorption of individual foetuses also might take place and that this would account for the small litter size. Therefore, normal and grafted mice of the $\mathrm{G}$ and $\mathrm{R}$ strains were killed at various times (9 to 20 days) during pregnancy and immediately post partum so as to compare the number of foetuses found in utero with the number of corpora lutea of pregnancy in the graft tissue. There was no evidence of any abnormal foetal mortality in either normal mice or graft recipients. The average number of foetuses found in utero was not significantly greater than average litter size, nor did examination of the uteri indicate that more than an occasional individual foetus had been lost. However, there was a discrepancy between the number of corpora lutea found in many of the grafts and the number of foetuses or live offspring (Table 8) and it must be assumed that the foetal loss occurred before implantation. Accordingly, a further small group of grafted mice was killed within 12 to $36 \mathrm{hr}$ of mating and the Fallopian tubes searched for ova. The numbers found were compared with the numbers of ruptured follicles or new corpora lutea in the grafts (Table 8). It is evident that more than half the eggs ovulated did not reach the Fallopian tube. 
Unfortunately, it was not realized at the time of this experiment that many of the grafts in this group of mice had few oocytes (half-ovary grafts, 56-day-old donors) and the numbers of ovulations were small. However, it is the difference between numbers of ruptured follicles and tubal ova that is relevant. This fact,

TABLE 8 CORRELATION BETWEEN NUMBERS OF FOETUSES AND NUMBERS OF CORPORA
LUTEA OR TUBAL OVA

\begin{tabular}{c|c}
\hline \multicolumn{2}{c}{ Normal G strain } \\
\hline Corpora lutea & Foetuses \\
\hline 4 & 4 \\
10 & 7 \\
6 & 4 \\
5 & 4 \\
5 & 5 \\
4 & 4 \\
\hline
\end{tabular}

\begin{tabular}{|c|c|c|c|c|c|}
\hline \multicolumn{6}{|c|}{ G strain grafts } \\
\hline \multicolumn{2}{|c|}{ Whole ovary } & \multicolumn{2}{|c|}{ Half ovary } & \multicolumn{2}{|c|}{ Whole or half ovary } \\
\hline Corpora lutea & Foetuses & Corpora lutea & Foetuses & Corpora lutea & Ova \\
\hline $\begin{array}{l}4 \\
2 \\
6 \\
4 \\
8 \\
3 \\
7 \\
4 \\
6 \\
9\end{array}$ & $\begin{array}{l}2 \\
2 \\
3 \\
4 \\
1 \\
3 \\
7 \\
3 \\
2 \\
5\end{array}$ & $\begin{array}{l}6 \\
6 \\
6 \\
6 \\
3 \\
3 \\
4\end{array}$ & $\begin{array}{l}4 \\
2 \\
3 \\
4 \\
2 \\
1 \\
2\end{array}$ & $\begin{array}{l}1 \\
3 \\
3 \\
4 \\
1 \\
4 \\
2\end{array}$ & $\begin{array}{l}0 \\
0 \\
1 \\
0 \\
1 \\
4 \\
1\end{array}$ \\
\hline
\end{tabular}

\begin{tabular}{|c|c|c|c|c|c|}
\hline \multicolumn{6}{|c|}{$R$ hybrid mice } \\
\hline \multicolumn{2}{|c|}{ Normal } & \multicolumn{2}{|c|}{ Whole-ovary grafts } & \multicolumn{2}{|c|}{ Half-ovary grafts } \\
\hline Corpora lutea & Foetuses & Corpora lutea & Foetuses & Corpora lutea & Foetuses \\
\hline $\begin{array}{r}3 \\
5 \\
11 \\
6\end{array}$ & $\begin{array}{l}2 \\
4 \\
9 \\
5\end{array}$ & $\begin{array}{l}8 \\
6\end{array}$ & $\begin{array}{l}3 \\
4\end{array}$ & $\begin{array}{l}5 \\
5 \\
6 \\
2\end{array}$ & $\begin{array}{l}1 \\
5 \\
1 \\
1\end{array}$ \\
\hline
\end{tabular}

and the discrepancy between numbers of corpora lutea and foetuses, demonstrated that the major cause of reduced litter size in grafted mice was the failure of a proportion of the shed ova to reach the Fallopian tube and be fertilized.

OBSTRUCTION OF PERIOVARIAN SPACE

Histological examination of the ovarian site showed that the grafts became vascularized from the vessels of the ovarian capsule so that some obstruction of the periovarian space was inevitable. 
Surgical interference was limited to a slit in the ovarian capsule, and in the most fertile recipient mice this was usually closed and there was a clear space both round the graft and between the graft and the Fallopian tube (Pl. 1, Figs. 3 and 4). If the capsule had remained open, the recipient was fertile only when most of the graft was retained in the capsule (Pl. 1, Fig. 1). However, complete infertility resulted when the capsule had folded back and the graft was separated from the Fallopian tube (Pl. 1, Fig. 2). This was a frequent occurrence when whole ovaries from adult donors were implanted. On the other hand, complete adhesion of the graft to the capsule was more usual when the donors were infantile. No mice were seen with the characteristic accumulation of fluid and inflation of the Fallopian tube that often follows surgical removal of the ovary (Parrott, unpublished data) and is due to damage or blockage of the Fallopian tube. No cysts of the type described by Jones \& Krohn (1960) were seen.

\section{TIME INTERVAL BETWEEN IRRADIATION AND GRAFTING}

Routinely, an interval of at least 4 weeks was left between irradiation and grafting so that the host ovary would be sterile at the time of operation. However, in a small group of $\mathrm{G}$ strain mice, donor tissue was grafted on the same day as irradiation. As a result, not only was the initial loss of oocytes from the graft tissue considerably reduced $(54 \%)$ but also the rate of loss was diminished (Text-figs. 4,5 and 6; Table 4). With respect to oocyte loss, this group seemed to be more comparable with normal mice than with those that were grafted several weeks after irradiation. It was estimated that, in both normal $\mathrm{G}$ mice and those grafted immediately after irradiation, the last 550 oocytes were lost in 240 days. The corresponding figure for all other grafted mice was 170 days. In consequence, the reproductive life of the recipients was extended to an ovarian age of 280 days, i.e. about 230 days after grafting (Pl. 1, Fig. 3). Despite the absence of delay between irradiation and grafting, no litters of mixed origin were obtained, all the offspring being genetically identified as deriving from grafted tissue.

It has been demonstrated that fertility can be restored to mice that have been sterile, as a result of irradiation, for as long as 3 months (Parrott, 1959a). This period has now been extended. Five surviving $G$ strain mice, out of a group of twenty that had been sterilized at 2 to 3 months of age, were grafted with tissue from 28-day-old donors 7 months later. Two of the animals mated and one became pregnant. There were established grafts (Pl. 1, Fig. 4) in all the five mice when they were killed 28 days after operation, but only one of the animals was fertile and this had six foetuses in utero.

\section{DISCUSSION}

The relationship between log. age and the number of oocytes in the ovaries of both normal and orthotopically grafted mice of the $G$ strain was found to be approximately linear. In considering the adequacy of the calculated oocyte-age curve in fitting the data (Text-fig. 1), it should be remembered that the few 
PLATE I

HISTOLOGICAL SECTIONS OF STERILIZED OVARIES ANID ORTHOTOPIC OIARIAN GRAFTS. ALL FROM G STRAIN MICE

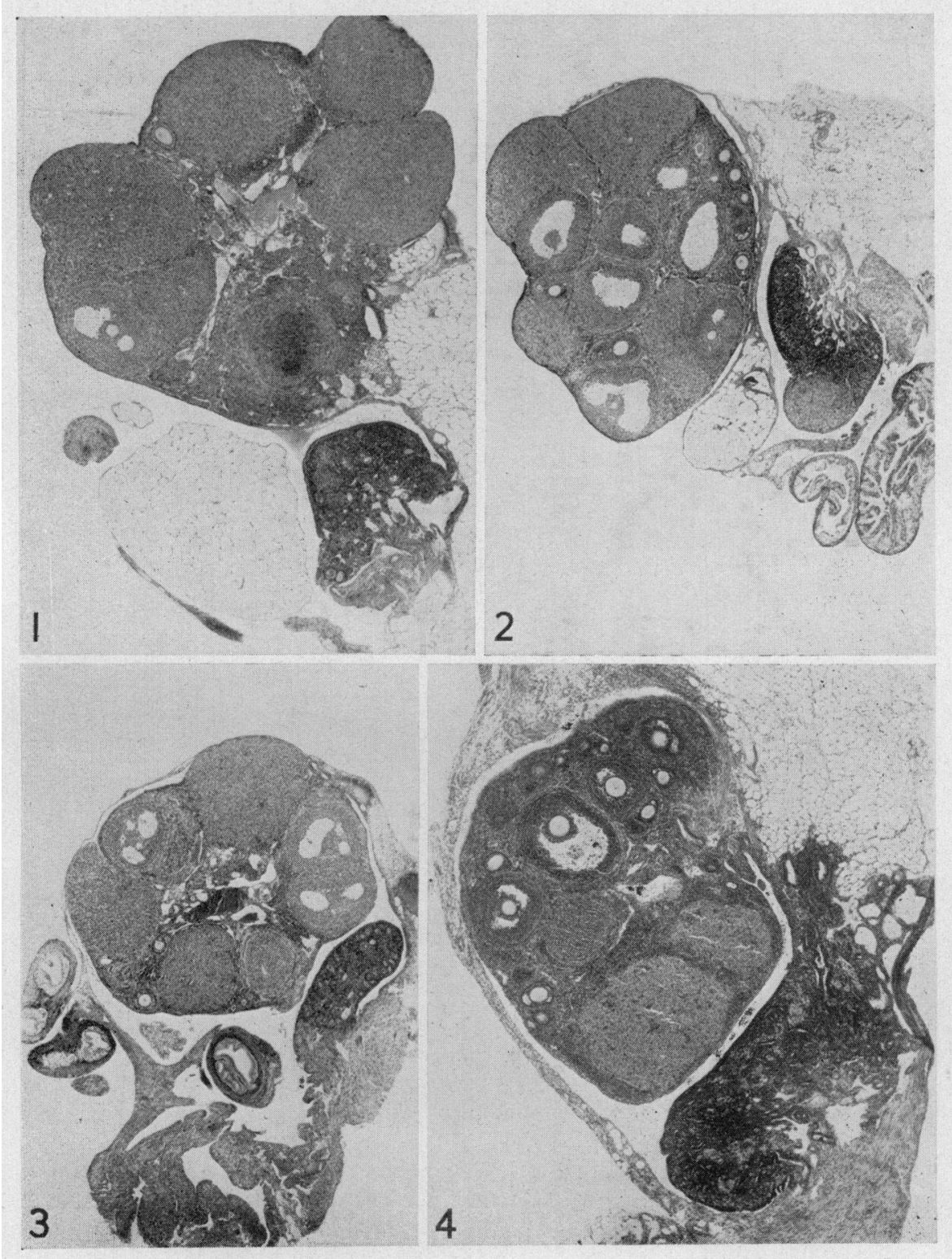

Fic, 1. Recipient killed 116 days after grafting, having had one litter of two, complete foetal resorption in another pregnancy and three pseudopregnancies. The ovarian capsule is open. (IMO 73.) $\times 22$.

FIg. 2. Recipient killed 54 days after grafting, having had three pseudopregnancies. The graft is attached to the outside of the capsule and the mouse is therefore infertile. (IMO 30.) $\times 18$.

Fig. 3. Recipient irradiated and grafted on the same day. It was killed 191 days later, having had four litters of three, three, four and three, and complete foetal resorption in a further pregnancy. (GOM 588.) $\times 18$.

FIG. 4. Recipient grafted 251 days after X-irradiation. It was killed 27 days after grafting when it was pregnant with six loetuses in utero (two dead). (GOM 629.) $\times 24$.

The ovarian capsule was closed in both Figs. 3 and 4 and clear spacc surrounds the grafts. In all Figs., the shrunken remnant of the irradiated ovary can be seen below or to the right of the functional graft. 
points at the lower end of the curve represent animals that survived to this age and are therefore a selected group. No attempt has been made to take account of this in the analysis, each point being equally weighted in the calculation of regression.

A linear relationship between log. oocytes and age, as found by Jones \& Krohn (1959), implies a constant percentage loss of oocytes during the whole life of the animal, but the linear relationship between log. age and number of oocytes, observed in the present experiments, implies an increase in percentage loss as the number of remaining oocytes becomes small, which seems more likely in practice.

The number of oocytes found in grafted tissue, and the subsequent loss, was shown to be equivalent for animals of the same ovarian age (i.e., age of donor plus the time between implantation and death) regardless of donor age and whether the grafts were of whole or half ovaries. It was estimated that the trauma of grafting resulted in about $65 \%$ of oocytes in the implanted tissue being lost at, or within a few days of, operation. Similar results have also been obtained by Jones \& Krohn (1960) with the more laborious technique of grafting after surgical ovariectomy.

The percentage loss of oocytes per 10 days was the same for both whole- and half-ovary grafts, but was greater than in normal ovaries of the same age. However, the actual number of oocytes lost per 10 days from the grafts was much less than from normal ovaries and appeared to be reduced to a minimum. Similar observations have been made by Mandl, Zuckerman \& Patterson (1952) with ovarian fragments in the rat.

A consequence of the reduced number of oocytes in the grafted tissue and the increased rate of loss was the curtailment of the potential reproductive life of the graft recipients from 400 to approximately 240 days. However, very few normal $\mathrm{G}$ mice became pregnant after 330 days of age, whereas it has been shown (Parrott 1960) that younger graft recipients can remain fertile virtually down to the last oocyte. In the present experiments, the $G$ strain recipients were killed before total loss of oocytes occurred and during the period of these experiments pregnancy occurred as frequently as in normal mice with the exception of recipients with half-ovary grafts from 56-day-old donors.

There was little correlation between the number of oocytes present in the graft tissue and the average size of litters born to both $G$ and $R$ strain recipients. In old normal mice with the same numbers of oocytes as the graft recipients, this correlation was good and the average size of litters was greater than with grafted mice. Undoubtedly, many factors outside the ovary contributed to the decreased fertility of ageing mice and it seems reasonable to assume that if oocyte reduction was the sole disability then the recipients of the young grafts ought to have had larger rather than smaller litters than their ageing counterparts.

There was no evidence to suggest that the proportion of follicles maturing was less in graft recipients than in normal mice with the same number of oocytes. On the contrary, counts of the numbers of corpora lutea showed that ovulations in the grafted mice were usually normal and that the main cause of small litters was the failure of a high proportion of the shed ova to reach the 
Fallopian tube. This was the result of either obstruction of the periovarian space and/or the failure of the ovarian capsule to close. Sippel (1947) reported a decreased fertility in mice after orthotopic autotransplantation which he ascribed to destruction of the periovarian space. Certainly, histological examination of grafts showed that absence of adhesions and closure of the capsule in individual graft recipients was associated with a history of almost normal fertility. The average size of litter born to recipients with half-ovary grafts was only slightly less than to those with whole-ovary grafts, despite the presence of only half the number of oocytes. It is probable that the smaller volume of tissue caused less intracapsular disturbance. Similar results have been obtained in hamsters (Parrott, 1959b), and Stevens (1957) found a significantly higher average litter size in recipient mice that had half- rather than whole-ovary grafts.

The reason for the large number of resorbed pregnancies, especially in the $\mathrm{G}$ and CBA strains with orthotopic grafts, cannot be decided. It seems unlikely that the resorptions were a manifestation of an immune reaction between the foetuses and foster mothers or they would have occurred more frequently in the hybrid $\mathrm{R}$ and outbred TO mice than in the inbred strains and not at all in normal mice. Nor is it probable that systemic effects of irradiation were implicated since resorptions were as frequent in mice that were sterilized by local irradiation to the dorso-lumbar region as in those sterilized by whole-body irradiation. Both progesterone and oestrone were given to CBA mice (Parrott \& Parkes, 1959), but the results were not conclusive and no other experimental evidence has been obtained.

The present work revealed several lines that could lead to improvements in technique and an increase in fertility of recipients. It is preferable to use either inbred strains of mice or $\mathrm{F}^{\mathbf{1}}$ hybrids of inbred strains so that the variable destruction of oocytes by homograft reaction is eliminated. At the same time, inbred strains such as the G or CBA strain have some disadvantages. The numbers of oocytes present in normal mice of the $\mathrm{G}$ strain is low, and resorption of pregnancy is a frequent occurrence in both strains. Probably, some other inbred strains would be more suitable and preliminary results with the AKR strain have shown that the numbers of oocytes surviving in the grafted tissue were greater and resorptions of pregnancy far less frequent than with the $G$ strain (Parrott, unpublished observation). Certainly, the results with $G$ strain demonstrated conclusively that the use of special inbred strains with genetic markers was not necessary with the technique of orthotopic ovarian grafting after X-irradiation, as no litters of mixed origin were obtained.

Recent work (Parrott, 1960) indicated that small doses of whole-body irradiation (200r) and medium doses of local irradiation (435r) to the dorsolumbar region were as effective as the large doses (900r) used in early experiments (Parrott \& Parkes, 1956; Parrott, 1959). The time interval between irradiation and grafting was not a critical factor in the establishment of grafts, but decreasing it had a marked effect not only on the initial oocyte loss but also on the rate of loss and as a result the reproductive life of the recipients was appreciably extended.

The age of donor and the size of implanted tissue had a considerable effect 
upon the subsequent fertility of recipients. Ovaries from adult donors of more than 50 days were the least suitable; the reduced number of oocytes shortened reproductive life and the larger volume of tissue increased the risk of splitting the ovarian capsule. Tissue from infantile donors (10 to 16 days) gave satisfactory results in the TO mice, but grafting ovaries from 19- to 28-day donors into $\mathrm{G}$ strain mice resulted in a very high proportion of foetal resorptions and increased the frequency of graft adhesion to the capsule. The most fertile $\mathrm{G}$ strain grafts came from 35- to 38-day-old donors; $\mathrm{R}$ mice donors were used only at this age but the recipients were among the most fertile of the mice with orthotopic grafts.

\section{ACKNOWLEDGMENTS}

We would like to thank Dr A. S. Parkes for the interest he has taken in this work. Miss A. Wakeford gave invaluable technical assistance and $\mathrm{Mr}$ J. B. Clark prepared the photomicrographs.

\section{REFERENCES}

Jones, E. G. \& KROHN, P. L. (1959) Influence of the anterior pituitary on the ageing process in the ovary. Nature, Lond. 183, 1155.

Jones, E. C. \& KRoHn, P. L. (1960) Orthotopic ovarian transplantation in mice. F. Endocrin. 20, 135.

Mande, A. M., Zuckerman, S. \& Patterson, H. D. (1952) The number of oocytes in ovarian fragments after compensatory hypertrophy. F. Endocrin. 8, 347.

Parrotr, D. M. V. (1958) Fertility of orthotopic ovarian grafts. Studies on Fertility, 9, 137.

Parrotr, D. M. V. (1959a) Ovarian grafting as a method for research into ageing. Gerontologia, 3, 91.

Parrott, D. M. V. (1959b) Orthotopic ovarian grafts in the golden hamster. F. Endocrin. 19, 126.

PARrotT, D. M. V. (1960) The fertility of mice with orthotopic ovarian grafts derived from frozen tissue. F. Reprod. Fertil. 1, 230.

Parrotr, D. M. V. \& Parkes, A. S. (1956) Orthotopic ovarian grafting after sterilisation by X-rays. Brit. vet. F. 112, 550 .

Parrotr, D. M. V. \& Parkes, A. S. (1960) Dynamics of the orthotopic ovarian graft. Sex Differentiation and Development. Mem. Soc. Endocrin., No. 7, p. 71. Ed. C. R. Austin. Cambridge University Press.

SIPPEL, T. O. (1947) The process of degeneration and recovery in ovaries transplanted autoplastically to the ovarian capsule in the mouse. Anat. Rec. 99, 570.

Stevens, L. C. (1957) Modification of Robertson's technique on homiotopic ovarian transplantation in mice. Transplant. Bull. 4, 106.

Zuckerman, S. (1951) The number of oocytes in the mature ovary. Recent Progr. Hormone Res. 6, 63.

Zuckerman, S. (1956) The regenerative capacity of ovarian tissue. Ciba Foundation Colloquia on Ageing, 2,31 . 